\title{
THE STUDIES ON ENGLISH FOREIGN LANGUAGE TEACHERS’ ICT - A REVIEW OF LITERATURE
}

\author{
WANG Xiaojun - DOSTÁL Jiří - AZIZ Avan Kamal, CZ
}

\begin{abstract}
Resumé
Nowadays, it is universally acknowledged that Information and communication technology (ICT) plays an important role in education. This study aims to investigate research on English foreign language (EFL) teachers' ICT competence, including pre-service EFL teachers' ICT competence and in-service EFL teachers' ICT competence within the last ten years between 2009 and 2018. The main contribution of this study is to find out what has been done on the topic and what needs to be further done. ERIC, Web of Science, ProQuest Education Database were searched to collect data on this topic. With criteria of inclusion and exclusion, a total of 13 studies related to EFL teachers' ICT competence were retrieved. The results indicated that there is an increasing trend of publications on EFL teachers' ICT competence over the last decade. The results also revealed that most of the studies concern in-service EFL teachers' ICT competence and studies related to pre-service EFL teachers' ICT competence were relatively few. And the target countries in the studies were Iran, Turkey, Norway, Morocco, Saudi Arabia, China, Malaysia, and Russia. To conclude, more studies need to be conducted on pre-service EFL teachers' ICT competence and future studies need to concern other countries except the above mentioned.
\end{abstract}

Key words: English, EFL, teacher, ICT competence

\section{SOUČASNÝ STAV VĚDECKÉHO POZNÁNÍ SE ZAMĚŘENÍM ICT KOMPETENCE UČITELŮ - ANALÝZA VÝZKUNÝCH STUDIÍ}

\begin{abstract}
V současnosti se všeobecně přikládá využívání informačních a komunikačních technologií (ICT) ve vzdělávání významná role. Proto si tato studie klade za cíl analyzovat stav vědeckého poznání se zaměřením na výzkum kompetencí učitelů anglického jazyka (jako cizího jazyka) v letech 2010-2018. Smyslem studie je zjistit, k jakým výzkumným závěrům se podařilo dospět a co je žádoucí dále zkoumat. Za tímto účelem byly prozkoumány publikace indexované v databázích ERIC, Web of Science, ProQuest Education Database. Na základě zvolených kritérií bylo extrahováno 13 studií $\mathrm{s}$ výše uvedeným zaměřením. Výsledky naznačily, že v posledním desetiletí narůstá zájem o výzkum ICT kompetencí učitelů anglického jazyka. Dále, že otázky spojené s pregraduální př́ípravou učitel anglického jazyka a rozvojem ICT kompetencí v jejím rámci, jsou řešeny minimálně. Zkoumané studie byly z autorského hlediska původem z Íránu, Turecka, Norska, Maroka, Saúdské Arábie, Č́ny, Malajsie a Ruska.
\end{abstract}

Klíčová slova: Anglický jazyk, učitel, ICT kompetence

\section{Introduction}

The last decade has witnessed an unprecedented development of technology. The advance of Information and Communication Technology (ICT) has brought changes to education. On the one hand, governments from all over the world have spent substantial funds in education in the form of technology, aiming to increase access to technology in educational institutions. Many studies have indicated that the efficiency and effectiveness of teaching and learning have improved after the 
implementation of ICT in the classroom. The benefits of using ICT in teaching process includes creating a more interactive learning environment; providing immediate feedback; improving communication and administration; enhancing critical thinking skills; etc. which has been substantiated by numerous studies (Barak, 2016; Simonova, 2015; Wang, 2015; Barrs, 2012; Wong, 2010). On the other hand, the aim of integration of ICT in classroom teaching is to achieve active learning, which requires changes in teachers' roles as well as students' roles in class. Under this circumstance, teachers act more like a facilitator than a teacher. They are more like the "guide on the side "instead of "the sage on the stage"(King, 1993). Accordingly, students become active learners instead of passive receivers. The changes require new competence of teachers, i.e. teachers' ICT competence or digital competence. That is to say, teachers need to be competent in using ICT tools in a digital teaching environment. Studies showed that although schools are adequately equipped with digital technologies such as computers, interactive whiteboards, language laboratories, digital networks, etc., the classroom teaching in many schools is still dominated by traditional teaching modes as teachers, in most cases, just use ICT tools for subject content delivery (Dostál 2017, Chaaban and Ellili-Cherif 2016, Alenezi,2015, Alzaidiyeen et al ,2010, Nikolopoulou \& Gialamas, 2015, Peeraer \& Van, 2015, Shapley et al, 2010). Studies also explicated that the main reason why teachers do not use new media in the EFL classroom is a lack of knowledge on how to use new media in the classroom (Helgesson, 2018; Holmberg, 2016).

ICT competence is the set of knowledge, skills, and attitudes (thus including abilities, strategies, values, and awareness) that are required when using ICT and digital media to perform tasks; solve problems; communicate; manage information; collaborate; create and share content; and build knowledge effectively, efficiently, appropriately, critically, creatively, autonomously, flexibly, ethically, reflectively for work, leisure, participation, learning, socializing, consuming, and empowerment (Ferrari 2012) . Competence is more than just knowledge or skills. It involves the ability to meet complex demands, by drawing on and mobilizing psychosocial resources (including skills and attitudes) in a particular context. For example, the ability to communicate effectively is a competence that may draw on an individual's knowledge of language, practical IT skills, and attitudes towards those with whom he or she is communicating (Rychen \& Salganik, 2003). Accordingly, ICT competence is a more comprehensive concept. The ICT skill is just a part of ICT competence. ICT competence includes knowledge and skills of using ICT as well as attitudes towards using ICT (Ananiadou \& Claro, 2009).

The European Commission's document “Key competence for lifelong learning” emphasizes the importance of eight new competence for every educator's lifelong learning: Literacy competence; language competence; science, technological, engineering and mathematical competence; digital competence; personal, social and learning competence; civic competence; entrepreneurship competence; and cultural awareness and expression competence. (European Commission, 2018). The ISTE (2009) (International Society of Technology in Education) issued the National Educational Technology Standards (NET-T) and performance indicators for Teachers. All teachers should meet the following standards and performance indicators: 1) facilitating and inspiring student learning and creativity; 2) designing and developing digital -age learning experiences and assessment; 3) modeling digital-age work and learning; 4) promoting and modeling digital citizenship and responsibility; 5) engaging in professional growth and leadership.

Without exception, information competence has become an indispensable competence for EFL teachers. It influences the professional level of future EFL teachers, their creative skills and abilities, and the development of new ways of teaching and learning English (Bondaruk, 2017). Attentions have been drawn to EFL teachers' ICT competence in recent years. This review examines studies on 
EFL teachers'ICT competence. The EFL teachers in this study include in-service EFL teachers and pre-service EFL teachers. This review attempts to answer the following questions:

1) What publication years do the studies relate to?

2) What target teachers do the studies relate to?

3) What target countries do the studies relate to?

4) What methodologies are adopted in the studies?

\section{Methodology}

\section{Data collection}

This review follows a process advanced by Creswell (2012) of conducting a literature review. The process includes the following five steps:

1) Identify key terms to use in your search for literature.

2) Locate literature about a topic by consulting several types of materials and databases, including those available at an academic library and on the Internet.

3) Critically evaluate and select the literature for your review.

4) Organize the literature you have selected by abstracting or taking notes on the literature and developing a visual diagram of it.

5) Write a literature review.

Two groups of keywords were used to search for related articles published between 2009 and 2018 from ERIC, Web of Science, ProQuest Education Database. The first group of keywords is "English teacher+ ICT competence", "English teacher + digital competence" and "English teacher +computer literacy". The second group of keywords is "EFL teacher+ ICT competence", "EFL teacher + digital competence" and "EFL teacher + computer literacy". A total of 13 studies on ICT competence of EFL teachers, including in-service and pre-service EFL teachers, were retrieved. The included articles needed to meet the following criteria:

- studies should concern the level or current state or the concept of in-service or pre-service EFL teachers' ICT competence, regardless of the level of schools or universities they teach,

- studies which only concerned the development of in-service or pre-service EFL teachers' ICT competence were excluded,

- studies which only concerned factors affecting in-service or pre-service EFL teachers’ ICT competence were excluded,

- $\quad$ the articles should be written in English language,

- books, dissertation, magazine article, reports on the topic were excluded.

\section{Data analysis}

The 13 included articles were read and analyzed following the process of coding and constant comparative analysis (Corbin \& Strauss, 2008). For example, articles on pre-service EFL teachers' ICT competence were coded with "pre-service" and articles on in-service EFL teachers' ICT competence were coded with "in-service". Likewise, articles that employed quantitative methodology will be coded with "quantitative" and articles that employed qualitative methodology will be coded with "qualitative". In this way, each article can have more than one code. After coding, the following categories are identified:

1) articles published in each year between 2009 and 2018,

2) articles published according to the target country,

3) articles published according to the target teacher,

4) articles published according to the methodology adopted. 


\section{Findings and Discussion}

\section{Publication statistics}

The number of articles published in each year between 2009 to 2018 is illustrated in Figure 1. Figure 2 shows the publication trends from 2009 to 2018. In 2013 and 2014, there is an increasing trend of reports, and in 2017, there is a significant increase in the reports published. In other years, there is either a decrease (2015-2016; 2018) or no reports published (2010-2012).

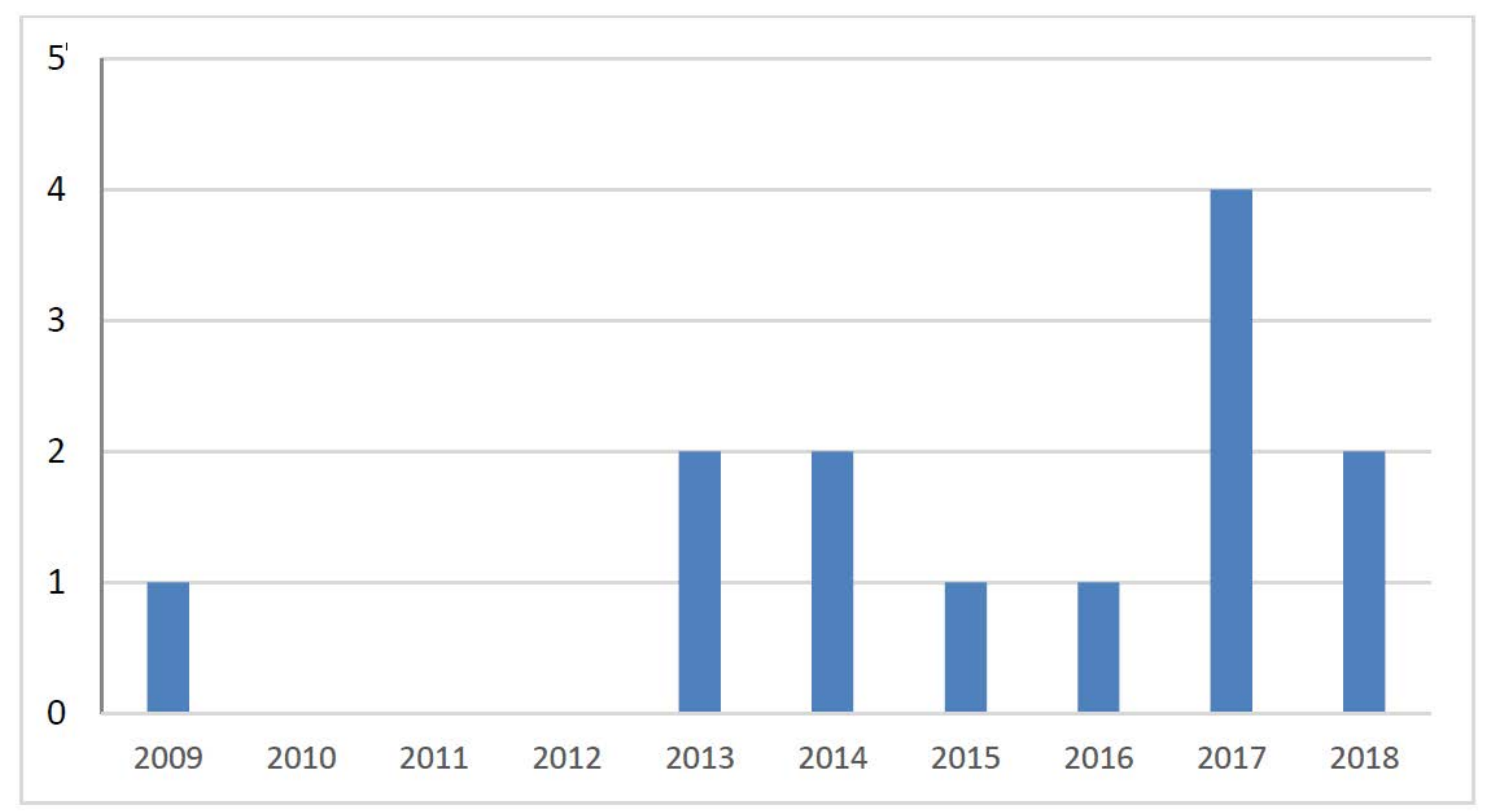

Figure 1 - articles published in each year from 2009 to 2018

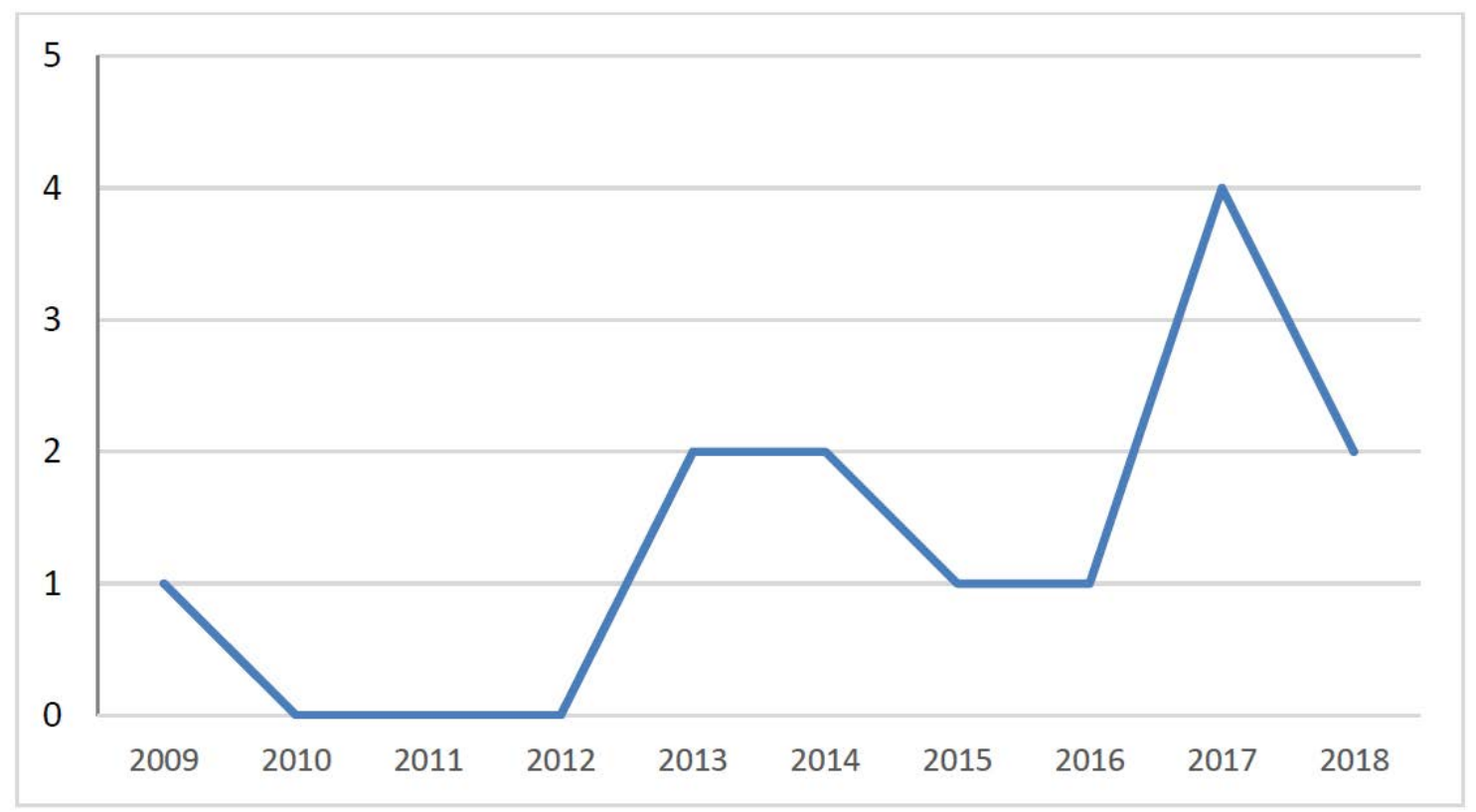

Figure 2 - Publication trends from 2009 to 2018 


\section{Articles published according to country distribution}

According to countries with which the publications are concerned, articles published from 2009 to 2018 mainly dealt with the following countries, including Iran, Turkey, Norway, Morocco, Saudi Arabia, China, Malaysia, and Russia.

\begin{tabular}{|l|l|}
\hline Article & Country \\
\hline $\begin{array}{l}\text { Jamalvandi et al (2017), } \\
\text { Jahanban-Isfahlan et al (2017), Dashtestani (2014) }\end{array}$ & Iran \\
\hline $\begin{array}{l}\text { Yildız (2017), İşler \& Yıldırım (2018), } \\
\text { Aydin (2013) }\end{array}$ & Turkey \\
\hline Røkenes \& Krumsvik (2016) & Norway \\
\hline Benali et al (2018) & Morocco \\
\hline Al Khateeb (2017) & Saudi Arabia \\
\hline Wang (2013) & China \\
\hline Razak et al (2009) & Malaysia \\
\hline Malinina (2015) & Russia \\
\hline Sysoyev \& Evstigneev (2014) & general \\
\hline
\end{tabular}

Table 1 - Overview of articles articles published according to country distribution

\section{Articles published according to the target population}

Examining the articles published according to teacher profile, most of the articles (about 70\%) focused on in-service EFL teachers' ICT competence. Little attention is paid to pre-service EFL teachers' ICT competence.

\begin{tabular}{|l|l|l|l|}
\hline Teacher & Pre-service & In-service & General \\
\hline Number & 3 & 9 & 1 \\
\hline Percentage & $23.1 \%$ & $69.2 \%$ & $7.7 \%$ \\
\hline
\end{tabular}

Table 2 - Overview of articles published according to the target population

\section{Methodology adopted}

With regard to the methodology employed in the research, quantitative methodology and mix method are popular with authors.

\begin{tabular}{|l|l|l|l|}
\hline Methodology & Qualitative & Quantitative & Mix method \\
\hline Number & 1 & 6 & 6 \\
\hline Percentage & $7.7 \%$ & $46.2 \%$ & $46.2 \%$ \\
\hline
\end{tabular}

Table 3 - Methodology adopted

\section{Limitation of the Study}

This review studies EFL teachers' ICT competence. Due to the strict criteria applied to include and exclude literature, this study has some limitations. irst of all, this review is not exhaustive as it only focuses on EFL teachers' ICT competence, i.e. the level or current state or components of EFL teachers' ICT competence. Studies which only concern how to develop EFL teachers' ICT competence or which factors affecting EFL teachers' ICT competence were excluded. In addition, the method used to search for the articles may lead to missing of some important articles related to the topic concerned in that only ERIC, Web of Science and ProQuest Education Database were sourced. The keywords used to retrieve articles in this study is another aspect of limitation as these keywords may not cover all the target articles. Other keywords, such as ICT literacy, technological literacy, computer competence, etc, can be also used for 
finding articles. However, this may result in an unmanageable number of data. The keywords used in the study are common terms.

\section{Conclusion}

The aim of this review is to examine studies on EFL teachers' ICT competence between the year 2009 and 2018. Compared with previous reviews related to the topic, most of which concern ICT competence of teachers or student teachers in all subjects, this review provides an explicit and specific perspective concerning ICT competence of EFL teachers instead of teachers of all subjects.

In general, there is an increasing trend of publications on EFL teachers' ICT competence in the last decade evidenced by the analysis in the findings. With regards to the number of articles published from the perspective of the relevant countries, Iran and Turkey were the main target countries followed by Norway, Morocco, Saudi Arabia, China, Malaysia, and Russia. Further studies should focus on other countries beyond the ones mentioned Scrutinized further, most studies concerned inservice EFL teachers' ICT competence. Studies on pre-service EFL teachers' ICT competence is relatively few. It is recommended that more attention should be paid to pre-service EFL teachers' ICT competence in future research.

\section{Bibliography}

Corbin, J., \& Strauss, A. (2008). Basics of Qualitative Research: Techniques and Procedures for Developing Grounded Theory (3rd ed.). Thousand Oaks, CA: Sage

Creswell, J. W. (2012). Educational research: Planning, conducting, and evaluating quantitative and qualitative research (4th ed.). Boston, MA: Pearson.

Barak, M., Watted, A. \& Haick, H. (2016). Motivation to learn in massive open online courses: Examining aspects of language and social engagement. Computer \& Education, 94, 49-60.

Simonova, I., \& Poulova, P. (2015). The Technology-Supported Learners' Activity towards Promoting Teaching/Learning. Procedia - Social and Behavioral Sciences 186, 1201 - 1207.

Wang, B. T., Teng, C. W. \& Chen, H. T. (2015). Using iPad to Facilitate English Vocabulary Learning. Int. Journal of Information and Education Technology, Vol. 5, No. 2,100-104.

Barrs, K. (2012). Fostering computer-mediated L2 interaction beyond the classroom. Language Learning \& Technology, 16(1), 10-25.

Wong, L.-H., \& Looi, C.-K. (2010). Vocabulary learning by mobile-assisted authentic content creation and social meaning-making: two case studies. Journal of Computer Assisted Learning, 26(5), 421-433.

Ferrari, A. (2012). Digital Competence in Practice: An Analysis of Frameworks. JRC Technical Reports, Institute for Prospective Technological Studies, European Union

Rychen, D. S. \& Salganik, L. H. (Eds) (2003). Key Competencies for a Successful Life and a WellFunctioning Society. Cambridge, MA: Hogrefe \& Huber.

Ananiadou, K. \& Claro, M. (2009). 21st century skills and competences for new millennium learners in OECD countries. Paper presented at the New Millennium Learners Conference, 21st Century Skills and Competencies, Brussels Department of Education.

European Commission (2018). Council recommendation on key competences for lifelong learning. Official journal of the European Union.

Dostál, J., Wang, X., Nuangchalerm, P. (2017). Experiments in Education Supported by Computer Use: Teachers' Attitudes towards Computers. In Proceedings of the 9th International Conference on Computer Supported Education (CSEDU2017)-Volum2, pages 248-254 
Chaaban, Y., Ellili-Cherif, M. (2017).Technology integration in EFL classrooms: A study of Qatari independent schools. Education and Information Technologies., 22(5), pp. 2433-2454 (2016). DOI:10.1007/s10639-016-9552-3.

Alenezi, A. (2015). Influences of the mandated presence of ICT in Saudi Arabia secondary schools. International Journal of Information and Education Technology, 5(8), 638-644.

Alzaidiyeen, N. J., Mei, L. L., Fook, F. S.: (2010). Teachers' attitudes and levels of technology use in classrooms: the case of Jordan schools. International Education Studies, 3(2), 211-218.

Nikolopoulou, K., Gialamas, V. (2015). Barriers to the integration of computers in early childhood settings: teachers' perceptions. Education and Information Technologies, 20(2), 285-301 (2015)

Peeraer, J., Van Petegem, P. (2015). Integration or transformation: looking in the future of information and communication technology in education in Vietnam. Evaluation and Program Planning, 48(8), 47-56.

Shapley, K.S., Sheehan, D., Maloney, C., Caranikas-Walker, F. (2010).: Evaluating the Implementation Fidelity of Technology Immersion and its Relationship with Student Achievement. Journal of Technology, Learning, and Assessment, 9(4)

Helgeson, J.(2018). English in the digital era: Swedish grades 4-6 teachers' use of pupil's extramural English experience of new media. Degree thesis. Dalarna University

Holmberg, J.(2016). Applying a conceptual design framework to study teachers' use of educational technology. Education and Information Technologies. 2017, 22(5), pp 2333-2349. DOI: 10.1007/s10639-016-9536-3.

Bondaruk, Y. (2017). The Development of Future Efl Teachers' Information Competence in Professional Training. Advanced Education 3(7): 45-50.

King, A. (1993 ). From Sage on the Stage to Guide on the Side. College Teaching, 41(1), 30-35.

ISTE. (2009). ISTE | About ISTE. Retrieved July 15, 2009, from

http://www. iste.org/am/template.cfm?section=about_iste

\section{Contact address:}

Xiaojun Wang, MA.

Faculty of Education, Palacký University, Žižkovo nám. 5, 77140 Olomouc, Czech Republic, phone: 00420585635 818, e-mail: xiaojun.wang02@upol.cz

Jiří Dostál, doc. PaedDr. PhDr. Ph.D.,

Faculty of Education, Palacký University, Žižkovo nám. 5, 77140 Olomouc, Czech Republic, tel.: 00420585635 818, phone: j.dostal@upol.cz

Avan Kamal Aziz, MA.

Faculty of Education, Palacký University, Žižkovo nám. 5, 77140 Olomouc, Czech Republic, tel.: 00420585635 818, phone: avan.aziz01@upol.cz 